\title{
GC/MS Analysis of Long-Chain Aldehydes from Recent Coral
}

\author{
Shigenori Ogihara \\ Earth and Planetary Science, Graduate School of Science, The University of Tokyo, Tokyo, Japan \\ Email: ogi@eps.s.u-tokyo.ac.jp
}

How to cite this paper: Ogihara, S. (2018) GC/MS Analysis of Long-Chain Aldehydes from Recent Coral. American Journal of Analytical Chemistry, 9, 46-51.

https://doi.org/10.4236/ajac.2018.91004

Received: November 27, 2017

Accepted: January 15, 2018

Published: January 18, 2018

Copyright $\odot 2018$ by author and Scientific Research Publishing Inc. This work is licensed under the Creative Commons Attribution International License (CC BY 4.0).

http://creativecommons.org/licenses/by/4.0/ Open Access

\begin{abstract}
The main objective of this study is to present the chromatograms and mass spectra of aldehydes so that geochemists could easily identify these compounds in sediment samples. Aldehydes are rare compounds found in the surface environment, particularly in sediments. To date, aldehydes have not been used as environmental proxies. In this study, long-chain aldehydes detected from coral collected from the east coast of Kenya are analyzed by gas chromatography mass spectrometry (GC/MS) using the typical procedure for biomarker analysis. The retention time of the long-chain aldehydes and fatty acid methyl esters slightly overlapped. Hence, the peak corresponding to the aldehyde in the GC chromatogram is buried with that corresponding to the ester, possibly overlooking the aldehyde. After assessing the difference in the retention time between the aldehydes and fatty acids methyl ester, the aldehydes were easily detected using the standard analytical procedure for biomarkers analysis. A molecular ion $\left(\mathrm{M}^{+}\right)$with greater than 23 carbon atoms was detected from long-chain aldehydes. The base peak was observed at $\mathrm{m} / \mathrm{z} 82$ in the mass spectra of the aldehyde, where characteristic $68+14 \mathrm{n}$ ions corresponding to even-numbered ions were observed. The M-18 ion, which was formed by the loss of $\mathrm{H}_{2} \mathrm{O}$, as well as $\mathrm{M}-46$ or $\mathrm{M}-84$ ions, was characteristic ions observed for long-chain aldehydes of the number of all carbon. The results obtained from this work, in which aldehydes were identified from coral samples, represent a good example of what could be achieved by geochemists when working with sediment samples and using aldehydes as environmental proxies.
\end{abstract}

\section{Keywords}

Aldehyde, Biomarker, Coral, GC/MS, Mass Spectra

\section{Introduction}

Hydrocarbons are the most used biomarkers for petroleum exploration and pa- 
leoenvironment analyses. Ketones and esters can also provide adequate information. The most representative examples are alkenones, which are used as paleoceanographic proxies [1], and fatty acids that serve as biomarkers of microalgae and bacteria [2]. Despite their similarities with ketones and esters, aldehydes are not employed as effective proxy biomarkers.

Few studies have reported the presence of long-chain aldehydes compared to other compounds in sediment surface samples. Previously, gas chromatography/ mass spectrometry (GC/MS) analyses of a stream deposit affected by industrial production activities revealed the presence of an aldehyde, possibly generated by the bacterial resolution of a high-carbon-number normal unsaturated compound [3]. Aldehydes with a high CPI (Carbon Preference Index) value have been detected from the surface sediment of the Unagi-ike pond, possibly indicative of an aldehyde from a high-vegetable land source [4]. Aldehydes reportedly detected from the sediment of the Spanish Cadiz Bay are classified into three patterns, i.e., 1) aldehydes originating from a land source corresponding to peaks of $\mathrm{C}_{28}-\mathrm{C}_{29}$, 2) aldehydes originating from an alga or a microorganism corresponding to peaks of $\mathrm{C}_{17}-\mathrm{C}_{19}$, and 3) mixture of the above two sources, respectively. The aldehyde distribution revealed the reduction environment of the surface sediment [5]. The abovementioned studies have not reported detailed MS analyses of the detected natural aldehydes.

In this study, the GC/MS analysis of long-chain aldehydes extracted from recently extracted coral is reported using standard conditions, i.e., no special equipment or methodology was used. The results obtained with this method helped to identify aldehydes in sediment samples. Based on this report, a new proxy, i.e., an aldehyde, can be used as a biomarker.

\section{Materials and Methods}

The analyzed coral sample was sampled by boring in the Malindi Marine National Park, located on the eastern coast of Kenya. The sample was collected 15 $\mathrm{km}$ southwest from the mouth of the Sabaki River in 2003. The coral core sample was dried at room temperature, and the coral core surface was scraped off to approximately $5 \mathrm{~mm}$ in thickness using a grinder to prevent contamination before powdering.

Traditional Soxhlet extraction using dichloromethane/methanol (93/7, v/v) was performed for $70 \mathrm{~h}$ to extract the biomarker. The extracted solvent was concentrated using a rotary evaporator. The isolated lipid was divided into four fractions using silica-gel column chromatography. A hydrocarbon fraction was obtained using two column volumes of $n$-hexane; a polyaromatic hydrocarbon fraction was obtained with two volumes of $n$-hexane/dichloromethane $(2 / 1, \mathrm{v} / \mathrm{v})$; an aliphatic ketone/ester fraction was obtained with seven volumes of $n$-hexane/dichloromethane $(1 / 1, \mathrm{v} / \mathrm{v})$; and a polar fraction was obtained with excess dichloromethane/methanol $(1 / 1, \mathrm{v} / \mathrm{v})$. Then, three fractions were examined via GC/MS: one corresponding to hydrocarbons, another to polyaromatics, and the 
other to aliphatic ketone/ester. A Shimadzu QP-2010 plus GC-MS system equipped with a 30-m fused silica capillary column (Thermo Scientific TG-5MS, $0.25 \mathrm{~mm}$ i.d., $0.25 \mu \mathrm{m}$ film thickness) and a splitless column injector was used. The following temperature program was utilized: isothermal conditions at $60^{\circ} \mathrm{C}$ for 1 $\min ; 60^{\circ} \mathrm{C}-175^{\circ} \mathrm{C}$ at $10^{\circ} \mathrm{C} / \mathrm{min} ; 175^{\circ} \mathrm{C}-225^{\circ} \mathrm{C}$ at $6^{\circ} \mathrm{C} / \mathrm{min} ; 225^{\circ} \mathrm{C}-300^{\circ} \mathrm{C}$ at $4^{\circ} \mathrm{C} / \mathrm{min}$; and isothermal conditions at $300^{\circ} \mathrm{C}$ for $20 \mathrm{~min}$. MS data were recorded in the electron impact mode at $70 \mathrm{eV}$ scanning from $\mathrm{m} / \mathrm{z} 50$ to $\mathrm{m} / \mathrm{z} 520$. This methodology corresponds to the typical analysis for biomarkers.

\section{Result and Discussion}

The analysis of the hydrocarbon and polyaromatic fractions of this study did not provide any useful information. However, in the aliphatic ketone/ester fraction, aldehydes were successfully detected. Figure 1 shows the analysis result (total ion chromatogram, TIC) for the ketone/ester fraction. A long-chain aldehyde $\left(\mathrm{C}_{19}-\mathrm{C}_{27}\right)$ did not predominantly exhibit an even number of carbons with $\mathrm{C}_{22}$ corresponding to the highest fraction. In contrast, $\mathrm{C}_{28}-\mathrm{C}_{30}$ aldehydes were dominant in the $\mathrm{C}_{27}-\mathrm{C}_{30}$ area. In addition, long-chain ketones such as $\mathrm{C}_{29}, \mathrm{C}_{31}, \mathrm{C}_{33}$, and $\mathrm{C}_{35}$ (keto-2-one, represented as $\otimes$-) were detected. Long-chain ketones with even-numbered carbons were not detected. The retention index of aldehydes was calculated based on the retention time of both fatty-acid methyl esters in the ketone/ester fraction and the $n$-alkanes in the hydrocarbon fraction. Table 1 summarizes the retention indexes and characteristic cleavage ions from long-chain aldehydes. The standardization based on the fatty-acid methyl esters is not general; it was rather performed to show the procedure to determine the retention time of aldehydes. Notably, the retention times of the long-chain aldehydes and fatty-acid methyl esters slightly overlapped. The peak corresponding to long-chain aldehydes was buried under the peak corresponding to the fattyacid methyl ester, and the resultant long-chain aldehyde was not detected from the analyses, where the content of the long-chain aldehyde is relatively less than that of the fatty acid methyl ester. Hence, few studies have reported the analysis of long-chain aldehydes.

The mass spectra of $\mathrm{C}_{26}$ and $\mathrm{C}_{28}$ long-chain aldehydes were recorded from $\mathrm{C}_{20}$ in Figure 2. The mass spectral feature of long-chain aldehydes was the presence

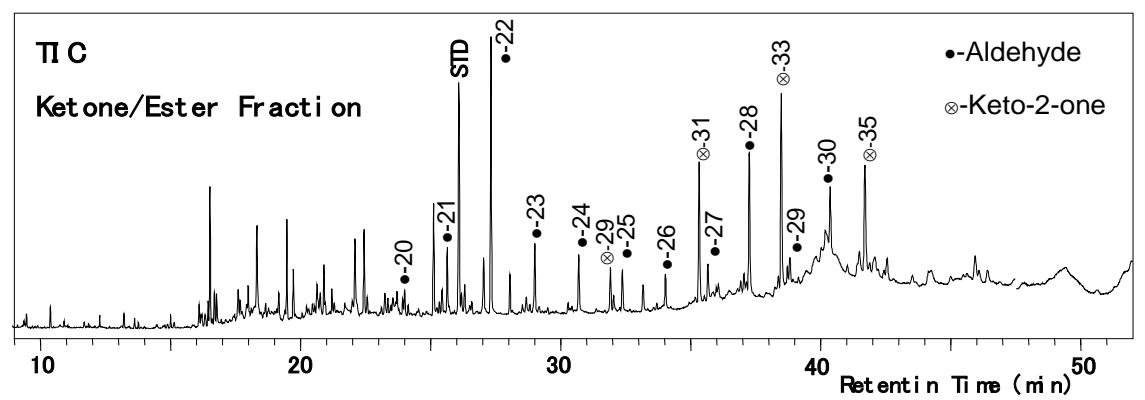

Figure 1. Total ion chromatogram (TIC) of ketone/ester fraction extracted from the coral sampled from the eastern coast of Kenya. 

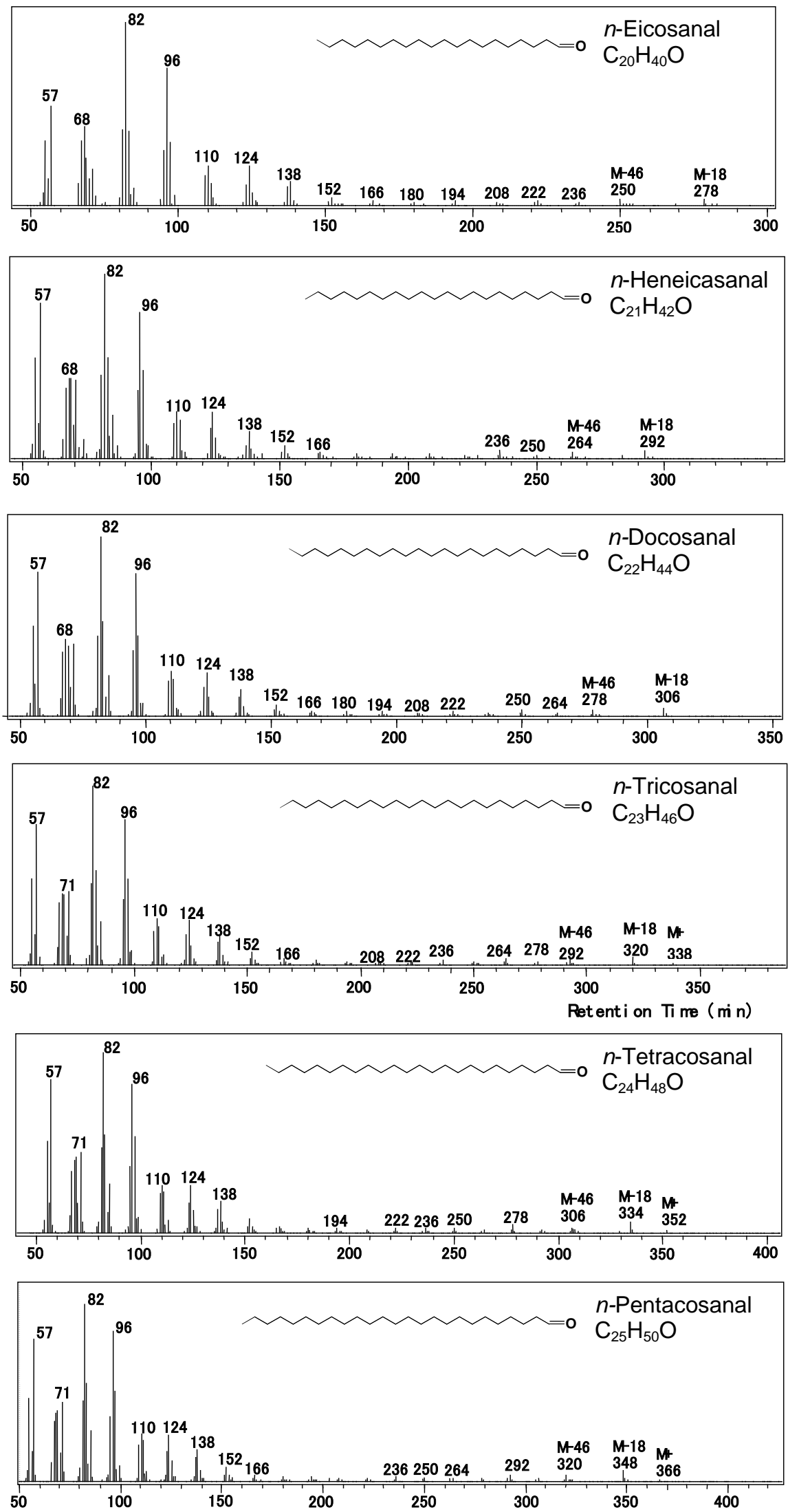

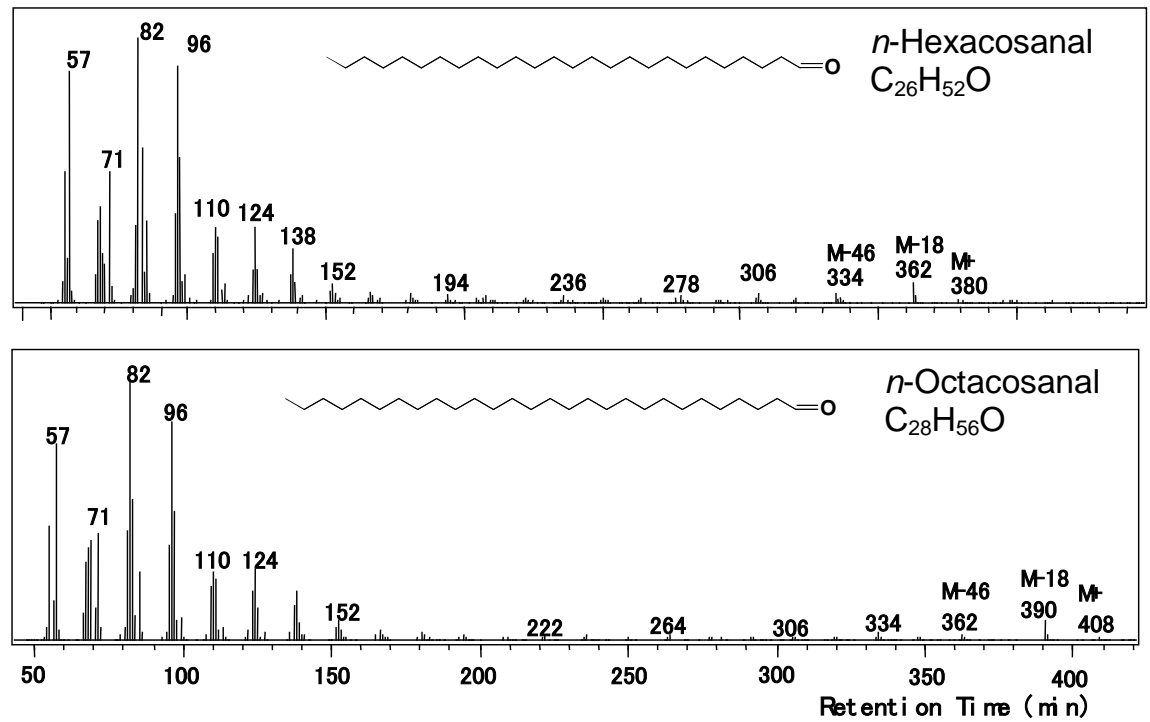

Figure 2. Mass spectra of the long-chain aldehydes from the coral sampled from the eastern coast of Kenya.

Table 1. Identification of long-chain aldehyde.

\begin{tabular}{cccccc}
\hline Compound & Formula & MW & Diagonistic ion $(m / z)$ & $\begin{array}{c}\text { *Retention } \\
\text { FAME }\end{array}$ & $\begin{array}{c}\text { Index } \\
\text { based on } \\
n \text {-alkane }\end{array}$ \\
\hline$n$-Eicosanal & $\mathrm{C}_{20} \mathrm{H}_{40} \mathrm{O}$ & 296 & $82,96,278(\mathrm{M}-18), 250(\mathrm{M}-46)$ & 1899 & 2226 \\
$n$-Heneicosanal $\mathrm{C}_{21} \mathrm{H}_{42} \mathrm{O}$ & 310 & $82,96,292(\mathrm{M}-18), 264(\mathrm{M}-46)$ & 2000 & 2354 \\
$n$-Docosanal & $\mathrm{C}_{22} \mathrm{H}_{44} \mathrm{O}$ & 324 & $82,96,306(\mathrm{M}-18), 278(\mathrm{M}-46)$ & 2102 & 2429 \\
$n$-Tricosanal & $\mathrm{C}_{23} \mathrm{H}_{46} \mathrm{O}$ & 338 & $82,96,320(\mathrm{M}-18), 292(\mathrm{M}-46), 338(\mathrm{M}+)$ & 2203 & 2531 \\
$n$-Tetracosanal $\mathrm{C}_{24} \mathrm{H}_{48} \mathrm{O}$ & 352 & $82,96,334(\mathrm{M}-18), 306(\mathrm{M}-46), 352(\mathrm{M}+)$ & 2304 & 2634 \\
$n$-Pentacosanal $\mathrm{C}_{25} \mathrm{H}_{50} \mathrm{O}$ & 366 & $82,96,348(\mathrm{M}-18), 320(\mathrm{M}-46), 366(\mathrm{M}+)$ & 2406 & 2735 \\
$n$-Hexacosanal $\mathrm{C}_{26} \mathrm{H}_{52} \mathrm{O}$ & 380 & $82,96,362(\mathrm{M}-18), 334(\mathrm{M}-46), 380(\mathrm{M}+)$ & 2507 & 2837 \\
$n$-Octacosanal & $\mathrm{C}_{28} \mathrm{H}_{56} \mathrm{O}$ & 408 & $82,96,362(\mathrm{M}-18), 390(\mathrm{M}-46), 408(\mathrm{M}+)$ & 2709 & 3040 \\
\hline
\end{tabular}

${ }^{*}$ Retention Index was calculated based on the retention time of FAME (fatty acid methyl ester) and $n$-alkane.

of a dominant base peak at $\mathrm{m} / \mathrm{z} 82$. A second or third peak was observed at $\mathrm{m} / \mathrm{z}$ 57 or 96 , followed by a peak at $m / z 110$ and even-numbered ions of $m / z 124$ or 138. The M-18 ion, which was formed by the loss of $\mathrm{H}_{2} \mathrm{O}$, and $\mathrm{M}-46$ or M-84 were characteristic for long-chain aldehydes of the number of all carbon. Even-numbered ions of continuation $\mathrm{m} / \mathrm{z} 82$ and 96 or 110 or 124 exhibited $68+$ $14 \mathrm{n}$, corresponding to ions that are absent in the other compounds and are characteristic for long-chain aldehydes. A molecular ion $\left(\mathrm{M}^{+}\right)$was not detected, and $m / z 71<m / z 68$ was characteristic of long-chain aldehydes by which number of carbon is less than 22 .

The peak corresponding to $\mathrm{m} / \mathrm{z} 82$ corresponded to cyclohexene formed by the McLafferty rearrangement; in addition, the peaks corresponding to $\mathrm{m} / \mathrm{z} 96$, 110 , and 124 corresponded to a C-6 ring structure [6]. 


\section{Summary}

The long-chain aldehydes detected from coral collected from the east coast of Kenya are analyzed by gas chromatography mass spectrometry (GC/MS) using the typical procedure for biomarker analysis. The detection of long-chain aldehydes needs to consider the overlap in the retention time with the fattyacid methyl ester. After assessing the difference in the retention time between aldehydes and fatty acids methyl ester, aldehydes were easily detected using the typical analytical procedure for biomarkers analysis. The following characteristics of the mass spectral peaks were confirmed by the GC/MS analysis of the long-chain aldehyde isolated from coral reefs. (1) An even-numbered molecular weight ion, corresponding to $m / z 68+14 \mathrm{n}$, where $m / z 82$ is the base peak; (2) M-18 by the loss of water; (3) A long-chain aldehyde was confirmed by (1); the number of carbons in aldehyde can be detected by (2) and the retention index despite the presence of a molecular ion $\left(\mathrm{M}^{+}\right)$.

Based on the results of this study, it is feasible to establish aldehydes as a new environmental proxy that can be useful when these types of compounds are found in surface samples.

\section{Acknowledgements}

The author wishes to express his gratitude to Professor H. Kayanne and his lab member Dr. N. Nakamura for supplying the coral sample.

\section{References}

[1] Sachs, J.P., Schneider, R.R., Eglington, T.I., Freeman, K.H., Ganssen, G., McManus, J.F. and Oppo, D.W. (2000) Alkenones as Paleoceanographic Proxies. Geochemistry Geophysics Geosystems, 1, 2000GC000059. https://doi.org/10.1029/2000GC000059

[2] Elvert, M., Boetius, A., Knittel, K. and Jørgensen, B.B. (2003) Characterization of Specific Membrane Fatty Acids as Chemotaxonomic Markers for Sulfate Reducing Bacteria Involved in Anaerobic Oxidation of Methane. Geomicrobiology Journal, 20, 403-419. https://doi.org/10.1080/01490450303894

[3] Steinheimer, T.R., Pereira, W.E. and Johnson, S.M. (1981) Application of Capillary Gas Chromatogram Mass Spectrometry/Computer Techniques to Synoptic Survey of Organic Material in Bed Sediment. Analytical Chimica Acta, 129, 57-67. https://doi.org/10.1016/S0003-2670(01)84119-2

[4] Kondou, H. and Ishiwatari, R. (1995) GC/MS Analysis of 2-Ketone and n-Aldehyde from Miike-Pond and Unagiike-Pond. Science Report, 52, 33-41. (In Japanese)

[5] Sánchez-Garća, L., de Andrés, J.-R., Marín-Rubí, González-Vila, F.-J. and Pplvillo, O. (2008) Use of Lipid Biomarker Patterns as a Proxy of Environmental Variability in the Coastal Sedimentary Record from Gulf of Cádiz (SW Spain). Organic Geochemistry, 39, 958-964. https://doi.org/10.1016/j.orggeochem.2008.03.013

[6] Christiansen, K., Mahadevan, V., Viswanathan, C.V. and Holman, R.T. (1969) Mass Spectrometry of Long-Chain Aldehydes, Dimethyl Acetals and Alk-1-Enyl Ethers. Lipids, 4, 421-427. https://doi.org/10.1007/BF02531017 